\title{
Looking Forward with Student Assistants
}

Miss Smith is librarian, Hiram College, Hiram, Ohio.

Oollege librarians have always been $\checkmark$ much concerned with ways and means of making student assistants of greater value to the college library, but there remains the 'student assistant's own side of the matter, which, perhaps, ought to receive more attention than we have been giving it. What are the needs of student assistants who are contemplating librarianship, and how can we be of more help to them without interfering with the service which we must have from them in order to carry on our own work? Is it possible to carry on a training program which will meet their needs and at the same time make them of greater value to us? $\vee$ It is because we have been attempting such a program at Hiram College that I have been asked to present this paper.

In justice to the student assistants, to our own institutions, and to the library profession, there are three services which we ought to render, viz., selection of those with aptitude for the task, sufficient instruction in library procedures to furnish a good background for work in a library school, and guidance in the selection of the college studies which are as essential in the preparation for librarianship as are premedical and pre-engineering courses for their respective professions.
When I was in library school, Dr. Melvil Dewey came to lecture to us on "The Qualifications of a Librarian." Almost the first thing he said was, "You can polish an agate but not a pumpkin." It is our business as college librarians to find the students who possess the qualifications essential for librarianship and interest them in the profession. It is also our business to squash the "pumpkins" who think they would like library work because they would always rather read than study or work.

A student assistant should be given as many of the widely taried tasks in the library as it is consistent with efficient service to give. He should have the opportunity to see all that will be required for success in the profession before he is permitted to enter upon professional training. Selection of student assistants by the librarian through a year's training and the rotation of library tasks to give familiarity with as many phases of library work as possible have been the outstanding features of our program. Because of the outstanding ability of our girls in library schools and in library work, the college was asked to give credit for the work and to expand our training to meet the requirements for teacher-librarian positions in high schools.

It has been suggested that before I outline these changes, which constitute the 
real subject of this paper, I review the essentials of the training program we have been carrying on for over twenty-five $\mathcal{}$ years.

The first things I learned upon assuming charge of the Hiram College Library were that there is no correlation between inability to finance a college education and aptitude for library work and that neither the director of admissions nor the deans were capable of selecting satisfactory library assistants either by their need or by their classroom grades. To remedy an impossible situation, I proposed conducting a library class throughout the year for the training of freshmen who might be interested, and choosing for paid assistants the ones in the class who rendered the best service.

This class met for instruction once each week, and each student gave two hours per week to supervised practice work. This gave us opportunity to judge both mental ability and character qualifications. It also served as sufficient introduction to the many phases of library work to enable the students to determine whether they wished to become librarians. There was neither tuition nor credit for the class. The course of study covered library arrangement and techniques and the use of library tools and reference books. It was planned to be of value to the student who wanted to know how to use a library efficiently as well as to the students interested in training for librarianship.

\section{Training Class Duties}

The students in the training class performed any kind of work which was needed. They did page work, filed cards, charged books, helped with invoicing, and mended books. It is possible we might have had better service if each student had been trained to perform one task, but the variety in the work helped mightily to popularize it and also gave us better insight into the student's capabilities.

Competition was keen because we never could employ more than half of the class on the paid student staff. $X$. The chance to retain the upper half of the class gave us superior students and obviated the difficulty of being asked to recommend inferior students to library schools. Under this system none but capable girls with aptitude for library work could become student assistants.

To enable these students who were taken on the student staff to grow in library work and assume more important tasks in their upper-class years, we then arranged a course in library techniques covering classification, cataloging, subject heading, administration, reference work and bibliography, and public documents. We divided these subjects into three years' work and rotated them so that any girl coming on the student staff in her sophomore year would get all of them. This gave a splendid background for entering library school and also supplied our own library with very efficient help. This class also met once each week and thus made it necessary for the librarian to teach two hours each week. However, the classes usually were held at hours when the library was not busy, and the advantage of having all of the student assistants together once each week for discussion of problems of administration partially compensated for the time the librarian spent away from her regular work. This system has proved very satisfactory, and we may regret having abandoned it this year in an effort to be of greater service both to the student assistants and to the state educational system of Ohio. 


\section{Needs of Rural High Schools}

The reason for the change in our program was a request from the state department of education for training to meet the requirements for teacher-librarians in the small high schools which cannot afford trained librarians.

I believe few librarians realize the pitiful condition of the libraries in the small high schools of the country. I know I was quite ignorant of their condition until I became one of the trustees of a public library which gives county extension service. Upon the creation of a large ordnance plant within the county and the consequent increase of population in all of the little villages and rural districts, I was asked to assume supervision of library extension to meet the emergency. This has taken me into many of the high school libraries. A few of them are quite well organized and are being efficiently managed by teachers who have taken enough interest in them to study what ought to be done. However, many of them have passed from teacher to teacher without any comprehension of how a library ought to be organized and are in a pitiful condition.

This is typical of what happens. A splendid teacher of mathematics, who has held her present position for fourteen years, was told on the day she reported for work this fall that this year her extracurricular task would be taking charge of the library. In this case there was a new school building and the books had been dumped in the room in utter disorder. Since there were no classification numbers in the books, it was impossible to get high school children to shelve them in any order. In the past an attempt at cataloging had been made by W.P.A. workers without any knowledge of cataloging. Of course it was worthless. This teacherlibrarian was also informed that there would be one thousand dollars to spend for books this year. She has no book selection tools and really knows nothing about the existence of such tools. When she asked some of the teachers in the school to hand in requests for books they would like to have, they said, "As librarian, the buying of books is your problem." What a plum for a book agent!

This poor teacher-librarian is allowed thirty minutes each day, free from class schedule but not free from room supervision, to bring order out of chaos and to select, order, classify, and catalog a thousand dollars worth of books. This would be an impossible task for the best trained librarian, but, when added to all of this is the fact that she has absolutely no knowledge of library techniques and library tools which would help her with her task, the impossibility of bringing order out of chaos is further magnified.

\section{The Teacher-Librarian}

The state department of education has been unable to enforce its ruling requiring the service of a half-time librarian in high schools, because there are no teachers equipped to give the needed service. Trained librarians can find full-time library positions. Moreover, very few of the trained librarians have the teacher certification necessary for the other half of the job.

Because some of our girls have made good in such positions, the department of education in Ohio asked Hiram College to give credit for our training program which would enable our girls to meet the requirements of the law. I was reluctant to make any change in our studenttraining program, because the plan which 
we have been using all of these years gave us such excellent student assistants. But when I considered that the only way an improvement could be made in the high school situation was through making a small beginning with the service of a teacher-librarian with sufficient training to demonstrate how useful a well-organized library can become, I thought we ought to try the proposed program. Also I realized that many of our girls feel that they must earn the money for their professional training after graduation from college. Here is a field in which they can render valuable service and at the same time earn the money for library school training. With this opportunity to continue library interests, these splendid girls, who have proved their fitness for library work and who have acquired the background to insure excellent work in library schools, will not all be lost to the profession, a situation which almost invariably occurs when they accept straight teaching positions. Here is a field for which there is no supply and in which there will be great demand if the department of education continues to push for better organization of high school libraries.

\section{Curriculum}

Our first task was to work out the curriculum for such a course. It was decided that the course ought to be divided into two halves of three hours' credit each. One half would include instruction in the use of library tools and reference books essential for efficient use of a library by any student and would be designated as a course in library research. The other half would be devoted to the techniques essential for doing a good job in a high school library and would be designated as a course in library techniques.
Both courses are required before students can secure positions as student assistants, but the course in library research is also open to students not interested in librarianship. This course is planned to be of value to students who expect to do graduate work or research work of any kind which will necessitate use of a library and is planned especially for teachers who expect to become school superintendents. It is so important that teachers know how to use library facilities for the enrichment of their classroom work that several states are considering including such a course in the general requirements for teacher certification. But it is even more important that school superintendents have such a course, since upon them will depend the responsibility for the proper organization of high school libraries.

\section{Library Research Course}

Our outline for this course is as follows:

Use of the library catalog, special

indexes, periodicals, etc.

Hours

Subject heading

12

Use of reference books

12

Bibliography

Total hours for library research course

The course in library techniques would include knowledge of all library procedures essential to the high school job. These techniques would be taught in simplified form so as to avoid the confusion of overspecialization. This course should also include instruction in young people's literature unless this subject is taught in some other course in the college. In many liberal arts colleges the literature classes are confined to adult literature, and students majoring in English or in literature graduate utterly un- 
aware of the splendid literature for children and young people. This wealth of material suitable for young people's reading can make a great difference in the reading habits of the next generation, and certainly anyone who is going to do work with young people in a library must have an introduction to the riches which are available. We who are interested in good reading habits ought to press for the inclusion of courses in literature suitable for high school in all teacher-training courses. I have sometimes thought that part of the responsibility for the popularity of cheap literature rests upon the English teachers who attempted to teach college literature in a college manner to young people who were not yet equal to it. Their consequent dislike of what was being taught resulting in a pendulum swing to the worthless, they have missed the excellent literature which they would have liked and which would have led to good reading habits and literary taste.

\section{Adapting Reading Programs}

High schools have come to a realization of the necessity for adapting reading programs to the age level and to previous reading experience, and $\mathrm{I}$ am sure all regular teacher-training institutions do offer excellent courses which enable English teachers to choose suitable material. My plea is that the liberal arts colleges which teach only the traditional literary subjects introduce a special course for English teachers. I have no argument for crediting a course in young people's literature toward an English major, but I do consider such a course indispensable for high school teachers and for high school librarians.

With all of these considerations in mind we adopted the following outline for our course in library techniques:

Library classification

Library cataloging

Library administration

Young people's literature

Total hours for library techniques 54

Our plan is to have two hours of laboratory work for all subjects except young people's literature, for which, of course, all of the time will be required for reading. For all other subjects there are either problems illustrating the instruction or actual library tasks within the field of the instruction. We believe that practice in the library is quite as essential for librarians as practice teaching is for teachers.

\section{Objectives of Teaching}

To teach in a way which will make the student self-reliant is of the utmost importance. Although we recognize the importance of giving the student knowledge of both library tools and library techniques, we still feel that the building of good work habits, the fostering of the right attitudes toward tasks, dependability, and resourcefulness are equally important with knowledge. These qualifications, all of which are vital to success, cannot be built in the classroom. These are qualities which we built under our old system. We are not yet sure that the program we are now attempting will give us sufficient opportunity for this development, and if we find that the increase in classroom instruction crowds out the building of capabilities, we will surely abandon the program.

I am not worried about the students who actually become student assistants after taking this training, for we will still 
have opportunity to train them in actual tasks. But we will have places for only a few student assistants, and I am worried lest the students who have earned classroom credits will think themselves capable of assuming teacher-librarian positions. We still have to work out a program which will combine more actual work in the library with classroom instruction.

\section{Intensive Study Plan}

In Hiram College we have unusual opportunity for student assistants to gain valuable experience under our intensive study plan. Under this plan a student concentrates most of his attention upon one subject for a period of nine weeks and covers a year's work in that subject. In addition to these intensive subjects, each student is expected to carry one running course with recitations three days each week throughout the year. There is six hours' credit for each intensive quarter and six hours' credit for a full year of each running course. Most of the language courses are given as running courses. Our library course, as set up at present, is one of the running courses with classes three times each week throughout the year. It is possible for a student assistant to drop an intensive course for one quarter and make up the credit lost by taking an extra running course, for example, the library course, and thus have the opportunity of working in the library full time (forty hours per week) for a period of nine weeks. Working in this way a student gains much more knowledge of library work than he does when working a few hours each week throughout the year. It is quite needless to say that he is of much more value to the library.

Another unique advantage at Hiram is the opportunity for all student assistants who are working intensively for one quarter to make some trips on the bookmobile which serves the rural sections of Portage County. This, of course, is only possible for student assistants who are working intensively in the college library, as otherwise a full day's trip would make serious inroads on college work. But under our intensive program it is possible for a student assistant working intensively in the college library any quarter to set up a schedule in which he will work one day each week at the public library, thus gaining an experience which is closer to what he will find in high school than the college library experience. The student would also develop a familiarity with young people's literature at the public library.

\section{Selection of College Subjects}

The third service which college librarians ought to render to students who are contemplating librarianship is guidance in the selection of college subjects which will make the greatest contribution to their professional success. Although most colleges offer premedical and pre-engineering courses, few have yet adopted prelibrarianship courses. The faculty member who knows nothing about the actual demands of library work glibly says, "Oh, you are going to be a librarian. Then, of course, you will want to major in literature." Now, as we all know, a librarian must have enough knowledge of many fields to understand the great variety of requests which come to her. It is as important for her to know the names of great musicians and artists as to know the names of great authors; as important to be able to serve chemists intelligently as to serve the members of the poetry club; as important to be able to keep books which will bear 
auditing as to be able to help with a bibliography on Greek drama; as important to know the art principles which will help her with the arrangement of her library and the layout of publicity posters as to be able to give a good book review.

It is clearly evident that if a student distributes studies over all of the fields in which a librarian must have at least a vocabulary knowledge, it will be quite impossible to take enough courses in any one subject to meet the major requirements. When the situation is further complicated by the requirements for entering library schools, the requirements for teacher certification, and the requirements for teacher-librarians, it becomes impossible to build up a subject major without leaving the student in absolute ignorance of many important fields of knowledge. With all of these requirements in mind, a functional major seems to be the only solution.

\section{Planning Functional Major}

In attempting to plan such a major we encountered a number of difficulties. Naturally such a program calls for too many subjects at the freshman level, since each subject is built in sequence requiring the freshman course as prerequisite to the upper-class courses. Nevertheless, I still feel that a librarian should have enough familiarity with each general division of the field of knowledge to understand its vocabulary, in preference to the lopsided education which must result from a subject major imposed upon the other requirements which we have already cited.

Since there is wide variation in the subjects which students submit for college entrance, there must be flexibility in the college program. It is impossible to think of a librarian rendering good service to a nature study class without some study in the field of biology. However, if she has had a good course in biology in high school, biology should be omitted to make place for some subject of which she knows nothing. Some students enter college with four years of some modern language, and faculty advisers recommend specialization in this language in which a reading knowledge is already gained, instead of recommending a reading knowledge of a number of languages, which would be of greater value to a librarian.

\section{Other Values in Education}

Not only must we consider the curriculum from the standpoint of a wise distribution of subject knowledge, but we must recognize that some subjects are important for the contribution they make to character. My grandmother, who never studied pedagogy but who was a successful teacher in an academy before the day of high schools, used to say, "Some subjects are needed to put twist into character." "Twist". to her meant the strength which was given yarn in the spinning. Without "twist" the yarn proved sleazy and worthless. Both wool and the time of spinning were wasted if the yarn lacked strength. Mathematics and courses which require painstaking laboratory work are such subjects, and some such subjects must be included to balance bookishness.

The case for functional majors was dramatically presented by Dr. Alexander Meiklejohn in an address which he delivered before an anniversary celebration in his honor last year. Because his experience is typical of the change in attitude which must come to all educators and institutions which frankly face the needs of the democratic society they serve, I quote: 
Thirty years ago I delivered an inaugural address at Amherst College. And among all the exciting incidents of that exciting day one incident has lingered in my memory with a poignancy exceeding that of all the rest. I can still shudder at the shock, the disturbance of it. As I advanced, line by line, page by page, through the text of that address, I suddenly found myself reading words whose meaning I could not accept as true. I can still recall how near I came to stopping. What should one do in such a situation? To myself I was saying, "I don't believe that. Why did I write it down?" What I wanted was time to think of something to put in its place. And yet I could not stop. ... The sentences, which at the very start of my career carried me to the edge of disaster, were saying that scholarship refuses to submit to certain practical demands which are made upon it. And in the face of that conflict I was taking the side of scholarship. Men of knowledge, I said, "are not willing to cut up their sciences into segments and allow the student to select those segments which may be of service in the practice of an art or profession." And what suddenly threw me back upon my heels was the realization that I was approving this "high-and-mightiness" of the scholar. I was lining up the teachers on the side of knowledge for its own sake as against knowledge for the benefit of mankind. "In one way or another," I said, "the teacher feels a kinship with the scientist and the scholar which forbids him to submit to this domination of his instruction by the demands of an immediate practical interest. Whatever it may mean," I continued, "he intends to hold the intellectual point of view and keep his students with him if he can.

"Scholars are not willing to cut up their sciences into segments and to allow students to select those segments which may be of service in the practice of an art or profession." Why not? What is knowledge for? Presumably the arts and professions are conducive to human welfare. Why, then, should not the sciences contribute to them in whatever ways they can?

\section{Objectives of Education}

That question which Dr. Meiklejohn faced at the beginning of his career can no longer be ignored by educational institutions if they are going to produce the leadership needed in a democracy. Education must be centered around the needs of the individual and aimed at making him of the utmost value to society.

It is possible that in an attempt to serve student assistants in the three ways mentioned-selection, training, and guidance-we may also serve greater social units. By selection of students with ability and aptitude for library work we make a valuable contribution to library schools and the library profession; by training student assistants to fill teacherlibrarian positions in small high schools we render valuable assistance to rural education and to the reading habits of a large part of our population who are without library service; by pressing for the adoption of functional majors we help to free our educational system of the outmoded practice of centering itself around subject matter instead of around the development of the individual to the limit of his capacity to serve society in his after-school life. 